\title{
The Global Land Grant University: What Does That Mean at Mizzou?
}

\author{
Brian Foster \\ Provost \\ University of Missouri
}

y topic for today is to try to see how our land grant status has impacted our
international initiatives - or, at least some of our initiatives. Like all of the
universities represented here today, MU is a very complex institution with a complex mission. I'll keep coming back to the point that we're a lot more than land grant-but that land grant status impacts all of what we are. So, let me start with the question of how we are a land grant university.

\section{MU: In what sense are we land grant?}

Of course, technically we are an 1860 land grant university and all that that means. Some of the underlying ideas are robust-have changed very little. But operationally, the "land-grant" idea has changed profoundly-even since 1960.

One of the most profound symptoms of change is the urban land grant movement. It is well known that urban universities have a mission much like land grant universities. They are very strongly oriented to serving the urban society in which they are located, providing support for urban social needs through educational programs and providing services. The "Urban 13," now expanded to include more urban schools, has put forward the idea of an urban land grant program analogous to the 1860 land grant act. It certainly is true that the 1860 land grant schools' mission is not strongly fixed on urban communities, and to the extent that it is, the land grant schools sometimes seem to compete with the urban university mission. Although it is unsure what will come of the urban land grant initiative, the discussion is symptomatic of a gap in the historic land grant movement on the one hand, but an affirmation of the significance of the movement on the other.

Another symptom of land-grant change is the significant change in Extension, one of the key elements of the land grant university. Perhaps most visible, the place of agriculture in the land-grant university has changed. It is still a very prominent part of Extension, but Extension is no longer "Ag Extension" in the sense that it once was. 4-H, for example, now has very large urban programs in Missouri. At MU, distance education support is housed in Extension-a very natural fit with the Extension mission, oriented toward public service, bringing education to the broad public. Similarly, support for small businesses has become a large element of Extension at MU- 
developing business plans, marketing plans, implementing IT systems, and other business functions. Again, this is very much a land-grant function, reaching out to the community in a direct and supportive way.

The point of these examples is, perhaps, that "land grant" is a mind-set. The organization has changed and will continue to change, but the mind-set is robust. Land grant is about public service. It involves cooperation with local communities. A land grant university is very outward looking. A big emphasis on bringing state-of-the-art knowledge to the public is central. Local application of state-of-the-art knowledge is a key element of the land grant university.

Having said all of this, it is important to note that the land-grant mind set is not all that MU is; it's a big piece, but it's not all there is. Even in relation to our traditional land grant constituency, $\mathrm{MU}$ is faced with a constant challenge of appearing elitist. We pay a big political price for this apparent elitism-a loss of the confidence of a key constituency. But even more important, we are often seen as the enemy of rural Missouri communities-or of inner-city communities, for that matter. From the standpoint of such communities, the University is an enemy in the sense that young people who attend MU are likely to get jobs outside their home-in Chicago, Denver, or other such placesabandoning home, community, church, family businesses, elder care responsibilities.

At least as important, universities are not good at communicating with the non-academic community. Academics talk in "academic speak" - a strange language that just doesn't make much sense to normal people. It's not just a matter of esoteric vocabulary-though that is a big part-but it's a cultural environment that just doesn't make sense to most people. We can't talk in a sensible way about liberal arts education-education that doesn't lead to a clear outcome like a good job. We cannot talk about research in a way that make sense to people-especially about basic research that has no obvious application. And in any case, many see the university as a home for a liberal/radical leftist faculty that violate all of their basic values.

\section{What is "Global Land Grant" about MU?}

This is an important question. Everyone in higher education is throwing around terms like "globalization," "global strategies," "international initiatives", and "global land grant." But the question is, how do these "ideas" really affect the organizational culture, structure, incentives, and real outcomes of comprehensive research universities? Plainly, what difference do these terms make?

I think the answer is "not much." You will see shortly that MU's international activities are extensive. They involve research, graduate and undergraduate instruction, Extension, and economic development. They are diffuse and deeply embedded across all colleges, and they flow from long and productive histories. Nevertheless, international programs are often marginal to the institution. They lack 
continuity, organizational support, centrality and a compelling narrative to build adequate political support. In short, they are interesting, challenging, productive-but they are not a key priority by consensus! We are globalbut under the radar.

Nevertheless, MU has a long history of international involvement. Consider the following.

- 1500 international students in 2007-08-about 5\% of total enrollment

- Numbers are dramatically up from 2001, especially at the graduate level

- About $70 \%$ of international students are graduate students

- Students come from 100 countries, approximately $70 \%$ from China, India, and Korea

- The international graduate students are critical to the STEM disciplines

- 1,000 international visiting scholars traveling on J-1 visas

- Visitors from 60 countries, most from China and Korea

- Most visiting scholars from College of Agriculture, Food, and Natural Resources, Journalism, Life Sciences and Asian Affairs

- More than 1,100 students earned academic credit abroad in 200708

- This is an increase from 450 in 2000

- Growth is due to rapid development of faculty-led courses, particularly in summer and intersession
- There is especially large growth in College of Agriculture, Food, and Natural Resources (CAFNR), the Journalism School, and the Trulaske College of Business.

- Ten years ago programs were mainly in Western Europe; now there are programs on all continents, with rapid increase in China.

- MU has dual degree programs with international partners in CAFNR, Engineering, Education, Nursing, and Public Affairs in Korea, Taiwan, Russia, and South Africa.

- Agricultural Extension has programs in New Zealand, Thailand, Australia, Ireland, and in other countries.

- MU has major externally-funded projects in China (seismology and water treatment), South Africa (seismology and phytology), East Africa (development and institutional capacity building), and India (nanosciences).

- MU has active agreements with over $\quad 160$ international universities and government agencies.

These international activities are extremely diverse in content, in location, in the nature of the collaborators, and in other dimensions as well. It seems that they can be grouped under four core global land grant themes at MU.

- Global citizenship

- Prepare students for cross cultural communication and professional practice...and for the pursuit of great opportunities and challenges 
that can be understood only at the global level (e.g., carbon dioxide emissions, energy, poverty, immigration, health disparities, and terrorism).

- Pursuing knowledge frontiers

- As at all other research institutions, academic scholarship has become a global practice. To advance and generate new knowledge, we must be able to reach, collaborate, and compete with colleagues and peers throughout the world. At Mizzou, our work in phytology, life sciences, nanosciences, seismology, geology, ecology, psychology, public health, archaeology, visual and performing arts, and humanities is deeply embedded in institutional relationships we forge across the world-on all continents.

- Building connections (for Missouri) to the global economy

- As a public university, one of our biggest responsibilities and challenges is to serve as an engine and a catalyst for the Missouri economy. We cannot really do that in the $21^{\text {st }}$ century without global reach, and without offering direct opportunities for linking Missouri constituents in the public, private, and non-profit sectors with our key international partners.

- Focusing on applications for local benefit

- The central land grant principle is to bring state of the art knowledge directly to people for application in their day to day lives. There is, thus, strong emphasis on local applications that benefit communities, families, local businesses, and other constituencies.

What the University of Missouri does to seed, cultivate, sustain, and harvest global initiatives is critical for the future of the University, the State of Missouri, and our citizens. These initiatives will be essential for recruitment and retention of the best and brightest faculty, staff, students, sponsors, and other key constituents at the University.

Not only is there a great deal going on at MU, but there is a long history of international initiatives. I can't give a comprehensive history of these activities, but it is important that we consider a sample of activities to give a sense of the diversity and continuity of international initiatives at the University.

- 100 years of the MU School of Journalism in China

- The School's first dean, Walter Williams, travelled extensively in China in the early 1900s.

- The first graduating class of the Journalism School included a Chinese student.

- Edgar Snow-very well respected-wrote key works on Chinese culture to American audiences.

- The Journalism School has remained active in China in consulting, training, and exchange.

- More than 50 Journalism students constituted a key part of the media coverage of the Olympics in China this year. 
- CAFNR has for decades pursued International Development Assistance, Extension, and research (see below for current programs)

- Extensive programs in Korea in the 1950s;

- A major presence in India for the Green Revolution;

- CRSP projects in North and East Africa, Indonesia, and Latin America;

- This work continues on a large scale in Kenya and Southern Sudan despite major funding reductions and changes at USAID.

- UM in South Africa at University of Western Cape (see below for details)

- More than 22 years ago, a strong collaboration with the University of Western Cape was established.

- Over 350 faculty from 40 departments have participated in exchange and research collaborations.

- Major NIH-funded research is now underway (see below).

This inventory of MU's international initiatives could be expanded dramatically. The point is that there are long-standing, robust international initiatives that constitute a strong foundation for our future as an international land grant university.

\section{Current International Projects}

With all of the above as background, let me turn to examples of the current projects in the "global landgrant arena" at MU. I have chosen four very different kinds of projects that illustrate the points outlined above. Here are four quintessential "land grant" projects, all international, all with substantial longevity, and all with the land-grant mind-set that I've described above.

FAPRI in Ireland and the UK. ${ }^{1}$ In the mid-1990s, in an academic meeting, the Prime Minister of Ireland learned about the work of MU's Food and Agricultural Policy Research Institute's (FAPRI's) analysis of agricultural policy in the United States. Upon the invitation of the Prime Minister, FAPRI began a longterm project that addressed the implications for Ireland of a series of agricultural policy reforms that the EU was considering. Ireland has a very large agricultural sector and is a major exporter of food products throughout the world. The EU policy objectives had implications for the Irish economy, and analysis of these changes for the Irish economy was essential. Upon the Prime Minister's invitation, the FAPRI project began in 1997.

Initially, the project was centered in Ireland-with the Irish Food and Agriculture Development Authority in Dublin and the Queen's University in Belfast, with strong connections to the Department of Agriculture, to industry, and to producer groups. With an MU faculty member (Bob Young) assigned full time in Ireland, the project trained new personnel and guided the early part of the policy analysis project. A strong team was formed that did the basic policy analysis of the Agenda 2000 reforms of the Common Agricultural Policy in 1998.

Since 1998, the FAPRI project has grown from a partnership with Ireland to a broader UK project. A variety of 
analyses have been conducted concerning the Common Agricultural Policy proposals of the trade liberalization under the Doha Round of the World Trade Organization, concerning greenhouse gas emissions and other topics, and in 2007 FAPRI's contracts for these policy analysis projects was extended for another three years.

The FAPRI analyses are based on models developed by research teams at MU. The project provides training, world price projections, and a general economic model for the rest of the EU. An important part of the methodology involves engagement of policy makers and industrial leaders. More recently, the Irish/UK participants in the project have engaged a broader set of EU participants, building models that have broader EU application.

\section{Pasture-based Dairying in} Missouri.2,3,4,5 Dairy production is a significant element of the Missouri economy. The state ranks $21^{\text {st }}$ in total milk production among states, but $7^{\text {th }}$ in the total number of licensed dairy operations. Dairy farmers earned \$298 million revenue in 2005 from milk, which translated into a total economic impact of $\$ 929$ million; moreover, there were 8,299 Missouri jobs, including direct, indirect, and induced multiplier effects in the dairy industry.

A new kind of dairy farm is emerging in Missouri, modeled on a pasture-based system of dairy production, much of which was developed in New Zealand. Since 2004, these pasture-based dairies have produced more than $\$ 12$ million in annual milk sales, with more than $\$ 37$ million in total economic impact, and 330 new jobs. By 2008, significant growth in this sector is expected, with projections of new investment at $\$ 63$ million, \$28 million in annual sales, \$87 million in annual economic impact, and 777 new jobs.

The social and environmental impacts of pasture-based dairying are as significant as the economic impact. It produces an environment with much less stress for families and the cattle than conventional dairy techniques. It also lowers the financial barriers to entry in the industry. Environmental impact is more positive as well.

The pasture-based dairying has been supported by a strong MU Extension project in Southwest Missouri. The program is taught through "core groups", training dairy farmers to become "expert producers," who then go on to help educate their neighbors. A valuable web resource has been developed that calculates pasture growth and utilization on a whole farm basis.

Moreover, the Missouri Extension team organized an international trip in 2008 to Australia and New Zealand, continuing the research that examines how producers there deal with drought stressed pastures, control animal heat stress, and study business processes such as transfer of ownership.

In short, the New Zealand connection, facilitated by MU Extension, has opened a new kind of dairy production that has had significant impacts on the Missouri economy, on local communities, and in general, on the quality of life in Missouri. 
MU Programs in East Africa. ${ }^{6}$ For thirty years, MU has had significant programs in Sub-Saharan Africa, particularly in western Kenya and, more recently, in Southern Sudan. In general, these programs arise from International Agricultural Programs, several of which are completed.

- A small ruminant research program from 1980 to 1998 sponsored by USAID. The program was designed to develop a system of goat production suited to small farms in Western Kenya. MU's part was the socio-economic components of the initiative.

- The Kenya Natural Agriculture Research Project, from 1989 to 2004, focused on enhancing the capacity of the Kenya Agricultural Research Institute (KARI). This \$30 million effort, led by $\mathrm{MU}$, included technical assistance, graduate training, and upgrading equipment. A related project trained Ph.D.s for KARI scientists.

MU's current project in Southern Sudan follows twenty-five years of civil war that has left millions of casualties and an extremely unstable political environment. In 2001, President Bush made it a high priority to broker an end to the conflict. He appointed John Danforth, former U.S. senator from Missouri, as envoy to the peace talks. In January 2005, a treaty was signed that creates a Government of National Unity and a semi-autonomous government for the Southern Sudan. In 2011 or 2012 a referendum will determine whether Southern Sudan will remain within the
Khartoum government or will become an independent nation.

MU's current project, the Southern Sudan Revitalization Project, will manage about $\$ 4$ million per year in facilitating activities of USAID in the area. Among other activities, MU will conduct a census that is necessary for the upcoming election. In addition, there will be work on such issues as land title laws and on creating viable government agencies. The MU project in Southern Sudan is seen as a possible model for addressing issues in Darfur.

University of Missouri and University of Western Cape. ${ }^{7,8}$ In the 1980s, MU, like other universities, saw significant campus pressure to divest investments in firms that did business with apartheid South Africa. A series of contentious events, including arrest of some students who were subsequently released on grounds of free speech, led to the formation of a committee to recommend whether the University of Missouri should divest its investments in firms that did business with South Africa. The Committee's response was that the University should divest...and, in addition, should establish a strong relationship with a university in South Africa. After some investigation of potential relationships, it was recommended that the University of Missouri pursue a relationship with the University of Western Cape.

A group of Missouri faculty and administrators visited the University of Western Cape, spending approximately two weeks on campus. They found significant resistance to a relationship with an American university, but they also saw a positive response to the 
visitors' extended stay on campus and their seemingly genuine interest in collaboration. A subsequent visit of Western Cape visitors to Missouri, though also showing some tensions, resulted in an agreement to collaborate in a variety of exchange arrangements.

This relationship has now lasted for more than twenty years, with several hundred exchanges. The MU Law School has a joint summer school project with courses that are co-taught by MU and UWC faculty; classes are half MU and half UWC students. The MU School of Health Professions' students can complete clinical internships in South Africa at UWC.

Currently, perhaps the most prominent MU program in South Africa builds on the remarkable array of 30,000 plant species, with more than 3,000 used in traditional, holistic medicine. A large majority of South Africans receive treatment from traditional healers, using traditional therapies developed over centuries, treating conditions ranging from the common cold to HIV AIDS. The effectiveness and safety of these therapies have not been scientifically addressed. The TICIPS program (The International Center for Indigenous Phytotherapy Studies), under direction of PI William Folk (MU Professor of biochemistry), is pursuing such studies, with the goal of incorporating these traditional therapies into conventional health care systems. The study is a randomized, placebo-controlled study looking at the safety and effectiveness of Sutherlandia for 124 volunteers at an early stage of HIV infection.

The study has engaged traditional healers in a central way. Dr. Kathleen
Groggin, Associate Professor of Psychology at the University of Missouri, Kansas City, says: “The traditional health providers are helping us in so many ways. They have helped give legitimacy to the study. They partnered with us in translation and in developing outcome measures. They will be helping us with patient retention. Above all, they are willing to try...Our colleagues are trusting that we...will work hand in hand." The study complies with all U.S. and South African regulations about the conduct of research, including conflict of interest and international property rights.

\section{Conclusion}

MU is a major research university with a very complex mission. The landgrant mind set is pervasive, including especially a profound commitment to serving the people of Missouri. Similarly, MU's international commitment is broad and longstanding - though perhaps not always focused and coherent. But it is clear that this international commitment shows a strong land-grant mind set. There is much more at $\mathrm{MU}$ than the land-grant mind set and mission-basic research, liberal arts education, and professional education, for instance. But the landgrant mind set has enriched all aspects of the complex MU mission.

\section{Acknowledgements}

I would like to thank Dr. Jim Scott, Associate Vice Provost for International Initiatives and Director of the International Center, University of Missouri, for his generous assistance in preparing this paper. He was very helpful in framing the land-grant concept in the international arena, and 
he put me in contact with others on campus who were extremely helpful in identifying the four projects described above. Accordingly, I'd like to thank my University of Missouri colleagues, David Baker, Ph.D. and Assistant Dean, Agriculture Extension, College of Agriculture, Food and Natural Resources; William Folk, Ph.D., Department of Biochemistry; and Michael Nolan, Ph.D. and Director, Division of Applied Social Sciences and Director, International Agriculture Programs. All were extremely helpful as I prepared the text for the four projects: for fact-checking, for providing references, and more generally, for their leadership in these important programs.

\section{References}

1. Binfield, J., 2008, "Background on the FAPRIIreland Partnership", FAPRI Special Report to Associate for ANR Extension.

2. Horner, J., R. Kallenbach, 2006, "Perspectives on Missouri Dairy Industry", ANR Extension 2006
Special Report PBS-1, (Developed for President's Pasture-Based Dairy Tour).

3. Rickard, T., J. Horner, S. Hamilton, K.

Kallenbach, W. Prewitt, 2006, "Significance of

Missouri Pasture-based Dairying", ANR

Extension 2006 Special Report PBS-3,

(Developed for President's Pasture-Based

Dairy Tour).

4. Kallenbach, R., T. Rickard, J. Horner, 2007, "Pasture-based Dairy Production", 2007 ODF Proposal and Annual Report.

5. Horner, J., 2008, "New Zealand Led Dairy Operations in Missouri, January 2008", Special Report to Associate Dean for ANR Extension.

6. Scott, James K., 2008, "Significant African Activities: Brief Summary, University of Missouri", Special Report to Provost.

7. "South African Education Program: The International Center for Indigenous Phytotherapy Studies (TICIPS)." University of Missouri System. 12 July 2008 http://www.umsystem.edu/ums/departments/ aa/southafrica/ticips/.

8. "International Team Studies South African Plant for HIVIAIDS." CAM at the NIH, Focus on Complementary and Alternative Medicine, Volume XIV, Number 4: Fall 2007. http://nccam.nih.gov/news/newsletter/2007_fa 1l/savisit.htm. 